\title{
Effect of Different Varieties and Sowing Dates on Growth, Productivity and Economics of Wheat (Triticum aestivum $\mathrm{L}$.)
}

\author{
Sanjay Singh Chauhan ${ }^{1 *}$, Anil Kumar Singh ${ }^{1}$, Shipra Yadav, \\ Sandeep Kumar Verma ${ }^{3}$ and Rahul Kumar ${ }^{2}$
}

\author{
${ }^{1}$ Narendra Deva University of Agriculture \& Technology, Kumarganj, \\ Faizabad-224 229 (UP) India \\ ${ }^{2}$ Sardar Vallabhbhai Patel University of Agriculture \& Technology, \\ Meerut-250110 (UP) India \\ ${ }^{3}$ Rama University,Mandhana, Kanpur-209217(UP) India \\ *Corresponding author
}

\section{Keywords \\ Wheat (Triticum aestivum L.), Sowing Dates \\ Article Info \\ Accepted: \\ 18 January 2020 \\ Available Online: \\ 10 February 2020}

\section{A B S T R A C T}

A field experiment was carried out at Agromet. Research Farm, Narendra Deva University of Agriculture \& Technology, Narendra Nagar (Kumarganj), Faizabad (U.P.) during Rabi season 2016-17 to study the effect of different dates of sowing on growth and yield of wheat (Triticum aestivum L.) cultivars. The experiment comprised of 9 treatment combinations and tested in randomized block design (RBD) with four replications. Experiment consisted of two factors, viz. dates of sowing and cultivars. Three wheat varieties, viz. Malviya-234, PBW-343 and NW-1012 were sown under three dates i.e. 20 November, 30 November and 10 December. Sowing dates and cultivars significantly influenced the growth characters of wheat crop. The crop sown on 20 November along with variety PBW-343 recorded highest initial plant population $\left(\mathrm{m}^{-2}\right)$, plant height $(\mathrm{cm})$, number of tillers $\mathrm{m}^{-2}$, dry matter accumulation $\left(\mathrm{g} \mathrm{m}^{-2}\right)$, leaf area index, days taken to $50 \%$ ear emergence and days taken to maturity as compared to rest of sowing dates and varieties. Highest net returns per rupee invested (1.33) was found with the variety 'PBW343 ' sown on 20 November.

\section{Introduction}

Wheat (Triticum aestivum L.) is one of the leading food crops of the world farming and occupies significant position among the cultivated cereals. Cultivation of wheat has been the symbolic of green revolution that played pivotal role in making the nation a food surplus nation. It belongs to poaceae family with chromosome number 42 and a self-pollinated crop. Wheat ranks first among the world food crops, in terms of cultivated area (223.813 mha) or production (733.144 $\mathrm{mt})$ and with productivity of (3280 $\left.\mathrm{kg} \mathrm{ha}^{-1}\right)$ (USDA 2016). It can be grown from below sea level to $5000 \mathrm{~m}$ altitude and in areas where rainfall ranges between $300-1130 \mathrm{~mm}$. Wheat contributes more calories $(20 \%)$ and 
more protein to the world's diet than any other food crop. The availability of wheat has increased from about $79 \mathrm{~g}_{\text {capita }}{ }^{-1}$ day $^{-1}$ to more than $185 \mathrm{~g}_{\text {capita }^{-1}}$ day $^{-1}$ despite the doubling of the population since 1961 (Bhardwaj et al., 2010).In India, wheat is the second most important cereal crop next only to rice and a key crop of the green revolution and post green revolution era. India stands second among wheat producing countries after China. During the crop year 2013-14, wheat was grown over an area of $31.18 \mathrm{~m}$ ha with the production of $95.91 \mathrm{~m} \mathrm{t}$ with an average productivity of $3.07 \mathrm{t} \mathrm{ha}^{-1}$ (DAC 2014-15). The demand of wheat in India by 2020 has been projected to be between 105109 million tonnes as against 93.88 million tonnes production of present day. In India, Uttar Pradesh state ranks first in both area (9.67 $\mathrm{m} \mathrm{ha})$ and production $(27.52 \mathrm{mt})$, but the average productivity is much lower (2846 $\mathrm{kg} \mathrm{ha}{ }^{-1}$ ) than Punjab (4307 $\mathrm{kg} \mathrm{ha}^{-1}$ ) and. Haryana (4213 kg ha-1), respectively (DAC, 2011). The wheat yields of western districts of U.P., are well comparable to adjoining Punjab and Haryana, but poor average yield of Eastern U.P., used to bring down the average productivity of the whole state. This clearly indicates that in spite of considerable improvement in genetic potential of the crop; productivity of wheat is very poor in the country as well as in the states in light of realized yield level of 45-50 q ha ${ }^{-1}$. Wheat area is decreasing every year and there is a very little scope for expansion of area in future. So, there is urgent need to vertical increase in yield per hectare to ensure household food security. This yield increase requires a continuing supply of improved germplasm an appropriate agronomy in order to sustain enhanced productivity and preserve the natural resource base. However, global warming, as a result of climate change, may negatively affect wheat grain yields potentially increasing food insecurity and poverty, although it should be noted that current effects of climate change in relation to wheat are inconclusive and model dependent (Tubiello et al., 2000). More recent and extensive research on climate change effects predicts marked increases in both rainfall and temperature, with temperatures projected to rise by as much as $3-4^{\circ} \mathrm{C}$ by the end of the century in South Asia (DEFRA, 2005). Predicted effects on wheat production include reduced grain yield over most of India, with the greatest impacts in the lower potential areas, for example in the eastern plains. Multiple cropping systems involving wheat often maximize profitability of the non-wheat cash crop components resulting in delayed sowing of wheat, subjecting it to suboptimal, often hotter, growing seasons. In the ricewheat system of eastern India, remote sensing studies revealed at least $60 \%$ of district wheat areas were sub-optimally, late planted. In many of the dry environments that suffer today from severe heat stress during grain filling, it has been shown that the enzyme soluble starch synthase in wheat appears to be rate limiting at temperatures in excess of $20^{\circ} \mathrm{C}$ (Keeling et al., 1994). Furthermore, the grain filling of wheat is seriously impaired by heat stress due to reductions in current leaf and ear photosynthesis at high temperatures. Ideally the best temperature regime during the wheat crop season is $20-22^{\circ} \mathrm{C}$ at sowing, $16-22^{\circ} \mathrm{C}$ at tillering to grain filling and slow rise of temperature to $40^{\circ} \mathrm{C}$ at harvesting (Sharma, 2000). However, the seed can germinate in the temperature range of $3.5-35^{\circ} \mathrm{C}$. A sudden increase in temperature for a period of 4-5 days at any stage of the wheat crop can adversely affect the crop yield (Spiertz et al., 2006) and even a one-day abnormal increase in temperature at grain formation and filling stage can result in large grain losses (Alexander et al., 2010). The rice-wheat is the most important crop sequence of Eastern region of Uttar Pradesh. Nearly 63 and 68\% of the total cropped area in kharif and rabi seasons are occupied by rice and wheat, 
respectively, and 70 to $90 \%$ of rice area covers under wheat cultivation. Based on physiography and farmer's conception of land utilization, the land type viz. upland, mid land and low land are identified. Among them the medium land is most important for rice-wheat cropping system. Although, low lands are exclusively utilized for growing rice and wheat, but the productivity of both rice and wheat from these lands is low. This low yield is primarily due to water stagnation and poor drainage. In a diagnostic survey, it was estimated that around $30 \%$ area of wheat is sown during the month of November; the ideal or normal sowing time, $50 \%$ of wheat is sown during December; the late sown wheat and rest $20 \%$ area is commonly sown during first fortnight of January; the very late sown crop. It has been realized that the average yield of wheat of this region, sown during the month of November, is well comparable to the state average, but the declining trend in wheat yield has been noticed with delayed sowing i.e. in the month of December and January. It is mostly due to shorter growth period available to late sown wheat coupled with high temperature and hot winds during reproductive growth period, which leads to forced maturity and ultimately poor grain yield. In addition to this, improper selection of varieties in this region, also affects the crop yield. At present there is a tremendous scope for increasing the yield of wheat with the use of multi-character high yielding varieties. The huge reduction in yield due to delayed sowing prompted us to evaluate optimum time of sowing for different varieties for maximum production.

\section{Materials and Methods}

The field experiment was conducted at Agromet. Research Farm, of Narendra Deva University of Agriculture and Technology, Narendra Nagar (Kumarganj) Faizabad (U.P.), during Rabi season of 2016-2017. The experimental site was situated about a distance of $42 \mathrm{Km}$. from Faizabad district headquarters at Faizabad-Raibareilly road at $26^{0} 47^{\prime} \mathrm{N}$ latitude, $82^{0} 12^{\prime} \mathrm{E}$ longitude and an altitude of 113 meters above mean sea level and is subjected to extremes of weather conditions. The total rainfall during course of experimentation was $16.8 \mathrm{~mm}$. During the crop season, the lowest temperature $\left(4.9^{\circ} \mathrm{C}\right)$ was recorded in the month of January and the maximum $\left(39.6^{\circ} \mathrm{C}\right)$ in the month of April. The highest mean relative humidity $(88.2 \%)$ was recorded in the month of January. The experiment was laid out in randomized block design with three varieties (HUW-234, PBW343 and NW-1012), three date of sowing and four replications. The experimental field soils having $\mathrm{pH} 8.2$, low EC 0.23 , organic carbon $0.37 \mathrm{~g} \mathrm{~kg}^{-1}$, available nitrogen $194.2 \mathrm{~kg} \mathrm{ha}^{-1}$, phosphorus $15.2 \mathrm{~kg} \mathrm{ha}^{-1}$ and potassium 250.2 $\mathrm{kg} \mathrm{ha}^{-1}$.

\section{Results and Discussion}

The plant height taken at 30,60, 90 days after sowing and at harvest stage. Plant height was significantly influenced due to different date of sowing and wheat cultivars at all the stages of crop growth except 30 DAS.The maximum plant height was recorded with 20 November date of sowing which was significantly superior over rest date of sowing at 60, 90 DAS and at harvest stage of the crop. Similar results were obtained by Jat et al., (2013), Mumtaz et al., (2015) and Kumar et al., (2016). Among cultivars Maximum plant height was recorded with PBW-343, which being at par to Malviya-234 and significantly superior over NW-1012 at 30, 60, 90 days after sowing and at harvest stage. Similar findings given by Musaddique et al., (2000) and Mattas et al., (2011) and Mumtaz et al., (2015). The number of tillers $\mathrm{m}^{-2}$ increase progressively at the successive stage of crop growth influenced by various date of sowing and cultivars. The maximum number of tillers 
was recorded with 20 November date of sowing which was significantly superior over 30 November and 10 December date of sowing. Such observations were also reported by Shahzad et al., (2007), Kumar et al., (2013). Among the cultivars PBW-343 was significantly superior over rest of the cultivars at all stages of crop growth. Similar results had also been reported by Dhaka et al., (2006) and Marasini et al., (2016).

In general, the dry matter accumulation increased with advancement in stages. As regards date of sowing maximum dry matter accumulation was recorded with 20 November date of sowing which was significantly superior over 30 November and 10 December at all the stages of crop growth except 30 DAS having nonsignificant effect on dry matter accumulation. Among cultivars maximum dry matter accumulation was recorded with variety $\mathrm{PBW}-343$ which was significantly superior over variety Malviya234 and NW-1012 at all the growth stages of crop up to harvest stage. Such observations were also reported by Singh (2005), Mattas et al., (2011) and Desmukhn et al., (2015). Maximum leaf area index was recorded with 20 November date of sowing which was significantly superior over 30 November and 10 December at all the growth stage except at 30 DAS having non-significant effect. Maximum leaf area index at 30 DAS recorded in variety PBW-343 which was significantly higher over rest of the cultivars. The same trend was noticed at 60 and 90 DAS. Increasing trend of leaf area index was observed with increasing the age of crop up to 90 DAS and with date of sowing.

Table.1 Effect of different date of sowing and verities on growth parameters of wheat cultivars

\begin{tabular}{|c|c|c|c|c|}
\hline \multirow[t]{2}{*}{ Treatments } & \multicolumn{4}{|c|}{ Growth Parameters } \\
\hline & Plant height (cm) & $\begin{array}{l}\text { Number of } \\
\text { tillers }\left(\mathbf{m}^{-2}\right)\end{array}$ & $\begin{array}{c}\text { Dry matter } \\
\text { accumulation }\left(\mathrm{gm}^{-2}\right)\end{array}$ & $\begin{array}{l}\text { Leaf area index } \\
\qquad(90 \text { DAS })\end{array}$ \\
\hline \multicolumn{5}{|l|}{ Date of sowing } \\
\hline 20 November & 93.4 & 466.3 & 914.33 & 5.17 \\
\hline 30 November & 90.2 & 420.7 & 855.17 & 4.17 \\
\hline 10 December & 85.6 & 399.6 & 812.41 & 3.96 \\
\hline SEm \pm & 1.23 & 7.07 & 13.76 & 0.08 \\
\hline $\mathrm{CD}(\mathrm{P}=\mathbf{0 . 0 5})$ & 3.63 & 20.77 & 40.40 & 0.23 \\
\hline \multicolumn{5}{|l|}{ Cultivars } \\
\hline Malviya-234 & 90.8 & 375.5 & 757.45 & 4.35 \\
\hline PBW-343 & 92.1 & 468.7 & 945.63 & 4.80 \\
\hline NW-1012 & 86.4 & 442.4 & 878.82 & 4.15 \\
\hline SEm \pm & 1.23 & 7.07 & 13.76 & 0.08 \\
\hline $\mathrm{CD}(\mathrm{P}=\mathbf{0 . 0 5})$ & 3.63 & 20.77 & 40.40 & 0.23 \\
\hline
\end{tabular}


Table.2 Effect of different date of sowing on yield and harvest index of wheat cultivars

\begin{tabular}{|c|c|c|c|}
\hline Treatments & $\begin{array}{c}\text { Grain yield } \\
\qquad\left(\mathbf{q ~ h a}^{-1}\right)\end{array}$ & $\begin{array}{l}\text { Straw yield } \\
\qquad\left(\mathrm{q} \mathrm{ha}^{-1}\right)\end{array}$ & Harvest index (\%) \\
\hline \multicolumn{4}{|l|}{ Date of sowing } \\
\hline 20 November & 39.60 & 54.77 & 41.97 \\
\hline 30 November & 35.77 & 50.43 & 41.50 \\
\hline 10 December & 33.98 & 46.83 & 42.03 \\
\hline SEm \pm & 0.36 & 0.83 & 0.75 \\
\hline$C D_{(P=0.05)}$ & 1.05 & 2.43 & NS \\
\hline \multicolumn{4}{|l|}{ Cultivars } \\
\hline Malviya-234 & 31.87 & 44.47 & 41.56 \\
\hline PBW-343 & 39.45 & 55.50 & 42.20 \\
\hline NW-1012 & 38.02 & 52.07 & 41.75 \\
\hline SEm \pm & 0.36 & 0.83 & 0.75 \\
\hline$C D_{(P=0.05)}$ & 1.05 & 2.43 & $N S$ \\
\hline
\end{tabular}

Fig.1 Mean weekly meteorological observations during crop season (November, 2016 to April, 2017)

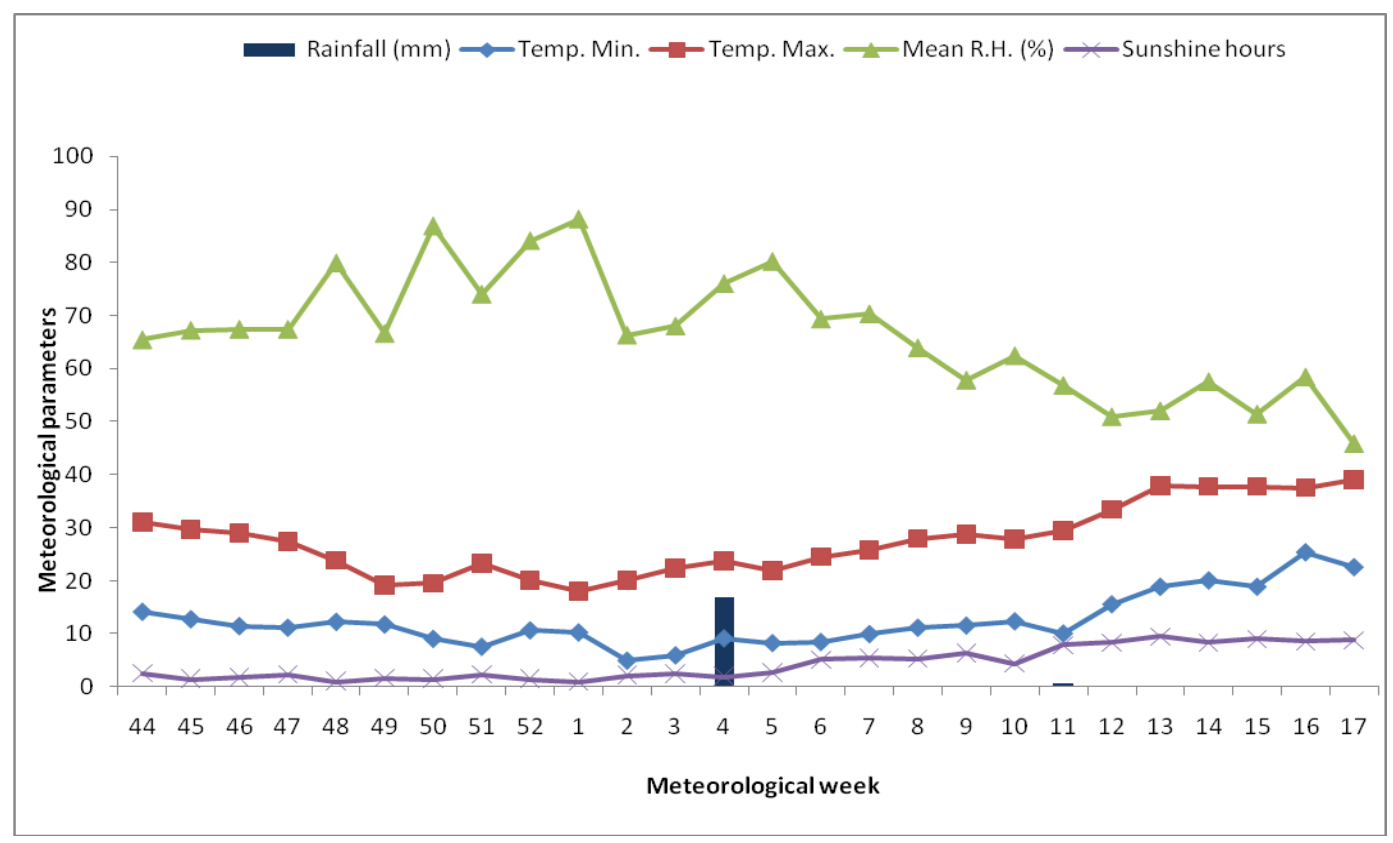


Fig.2 Effect of different date of sowing on plant height of wheat cultivars

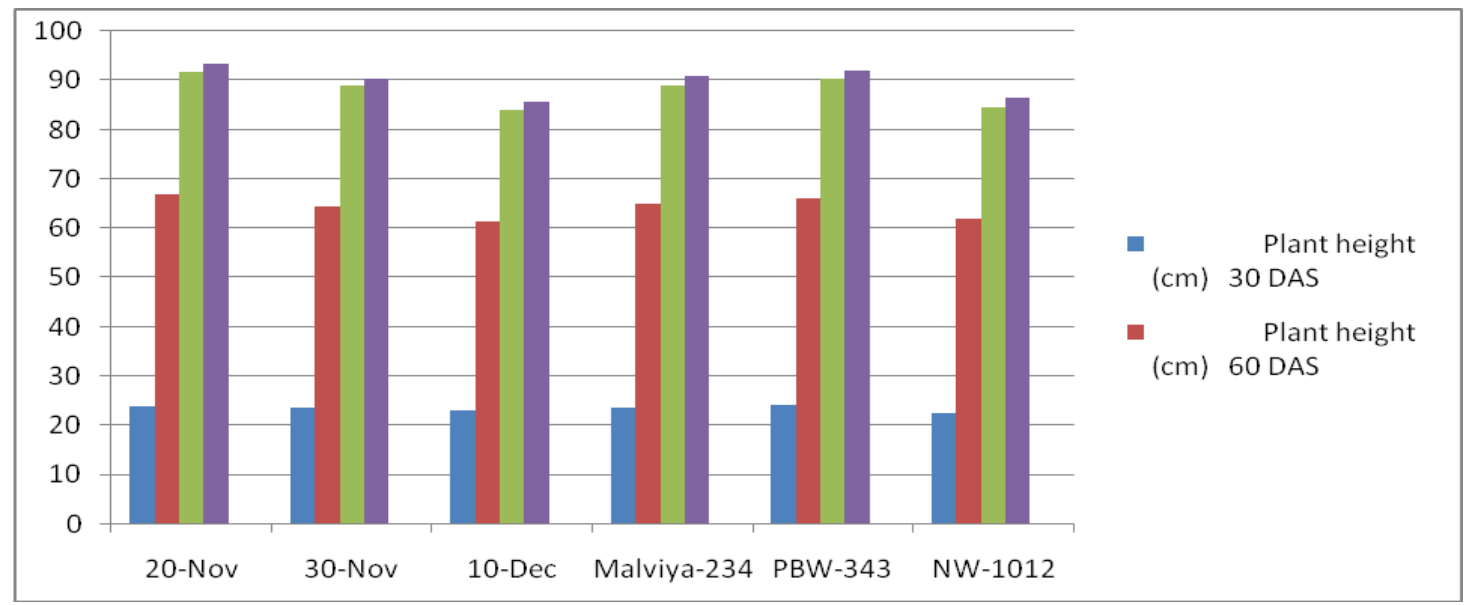

Fig.3 Effect of different date of sowing on number of tillers of wheat cultivars

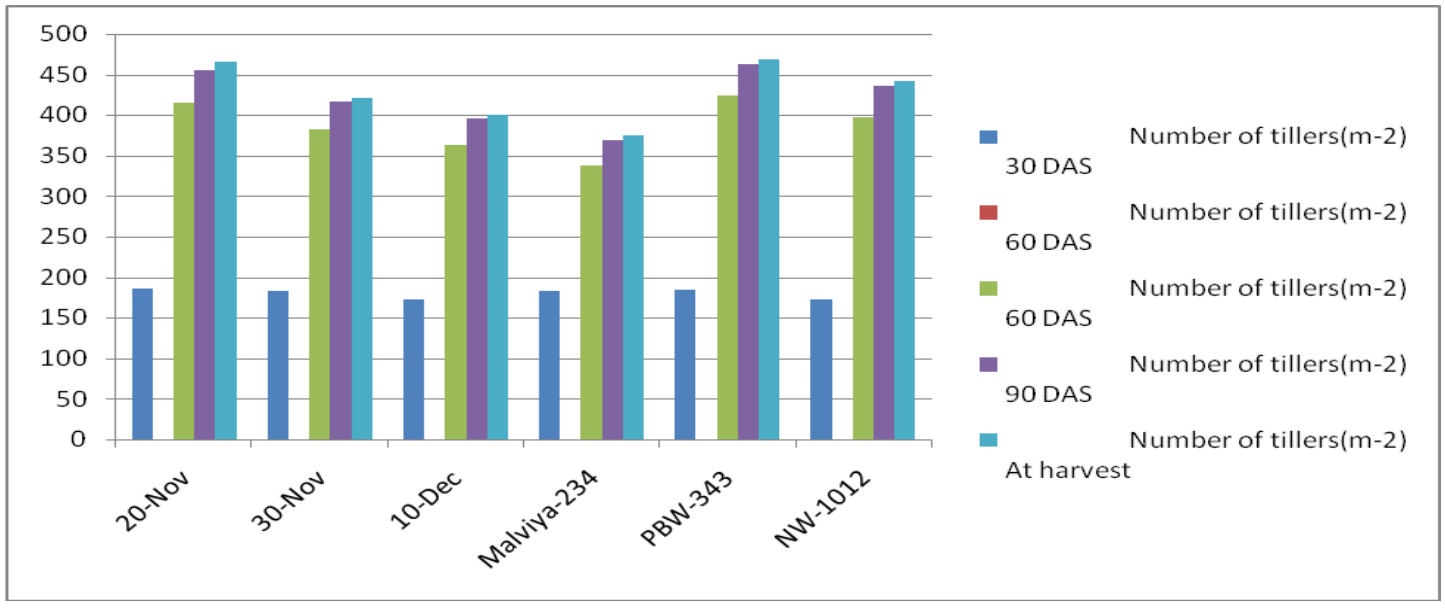

Fig.4 Effect of different date of sowing on dry matter accumulation of wheat cultivars

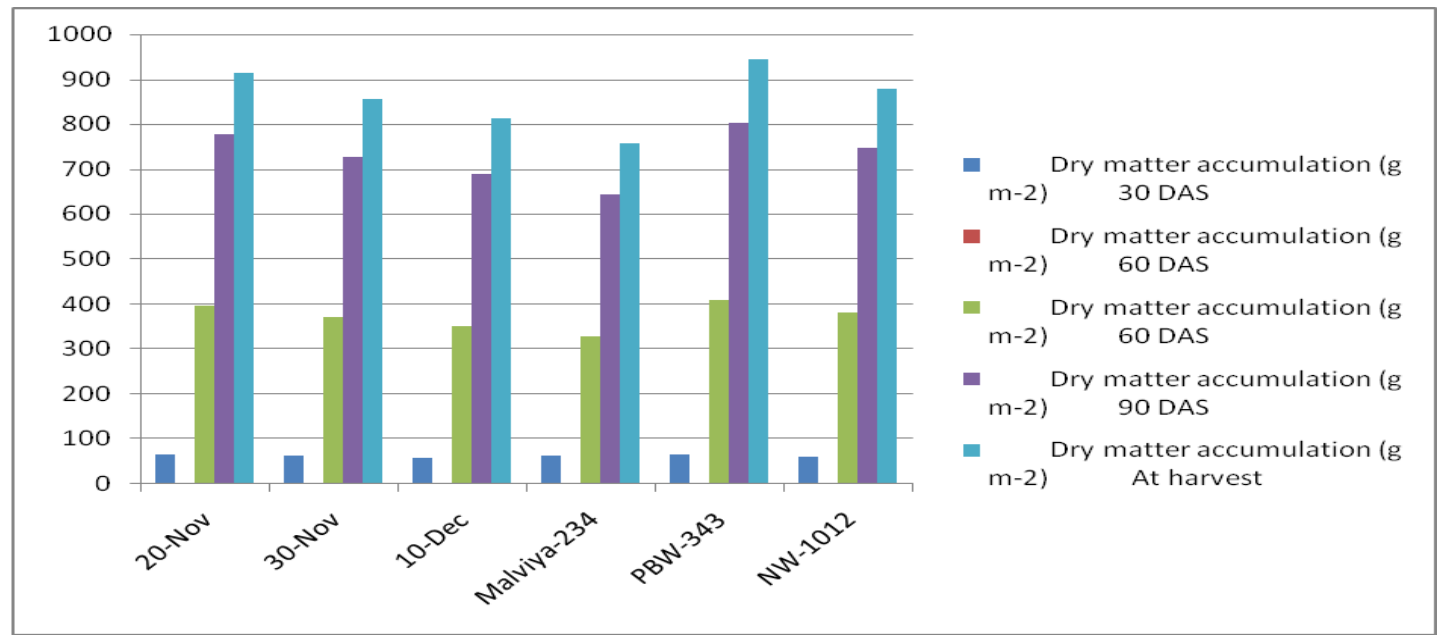


Fig.5 Effect of different date of sowing on leaf area index of wheat cultivars

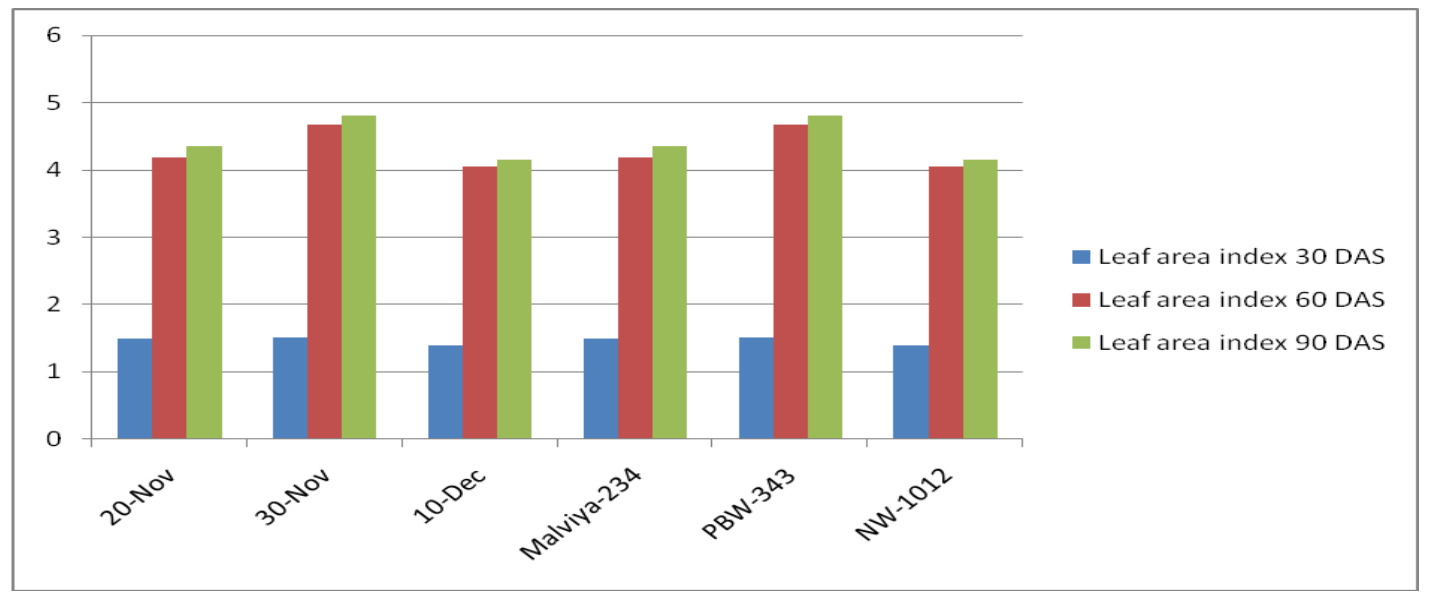

Fig.6 Effect of different date of sowing on days taken to $50 \%$ ear emergence and days taken to maturity of wheat cultivars

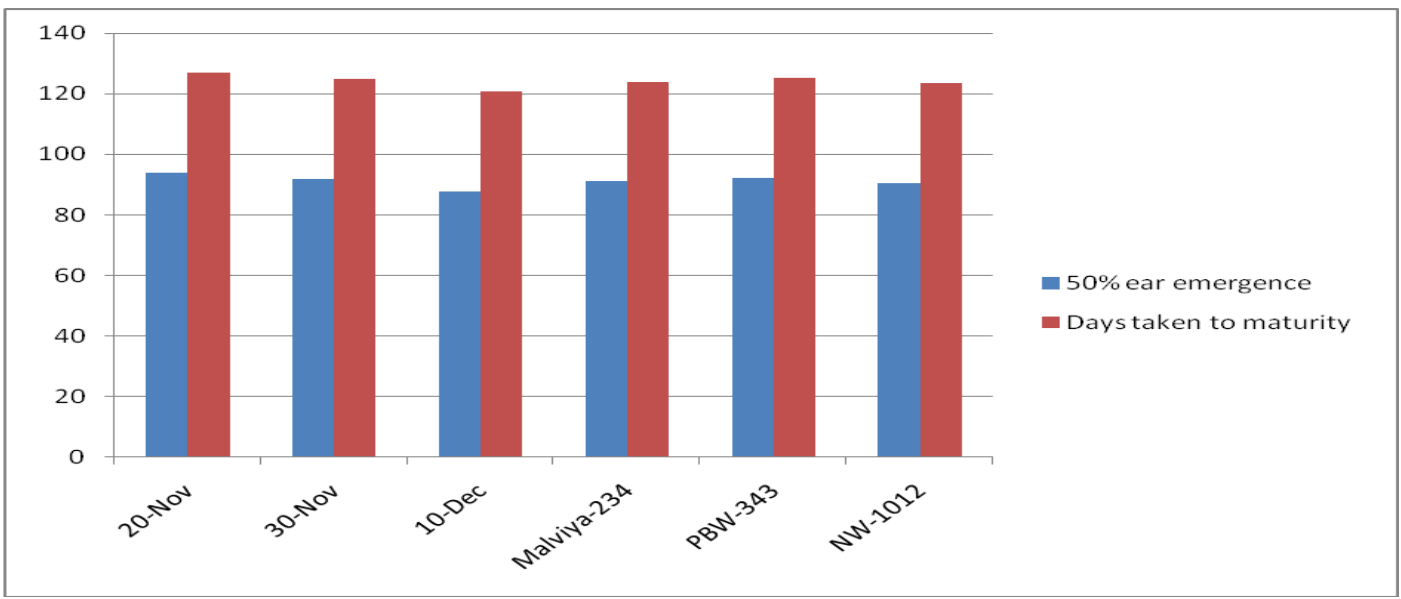

Fig.7 Effect of different date of sowing on yield and harvest index of wheat cultivars

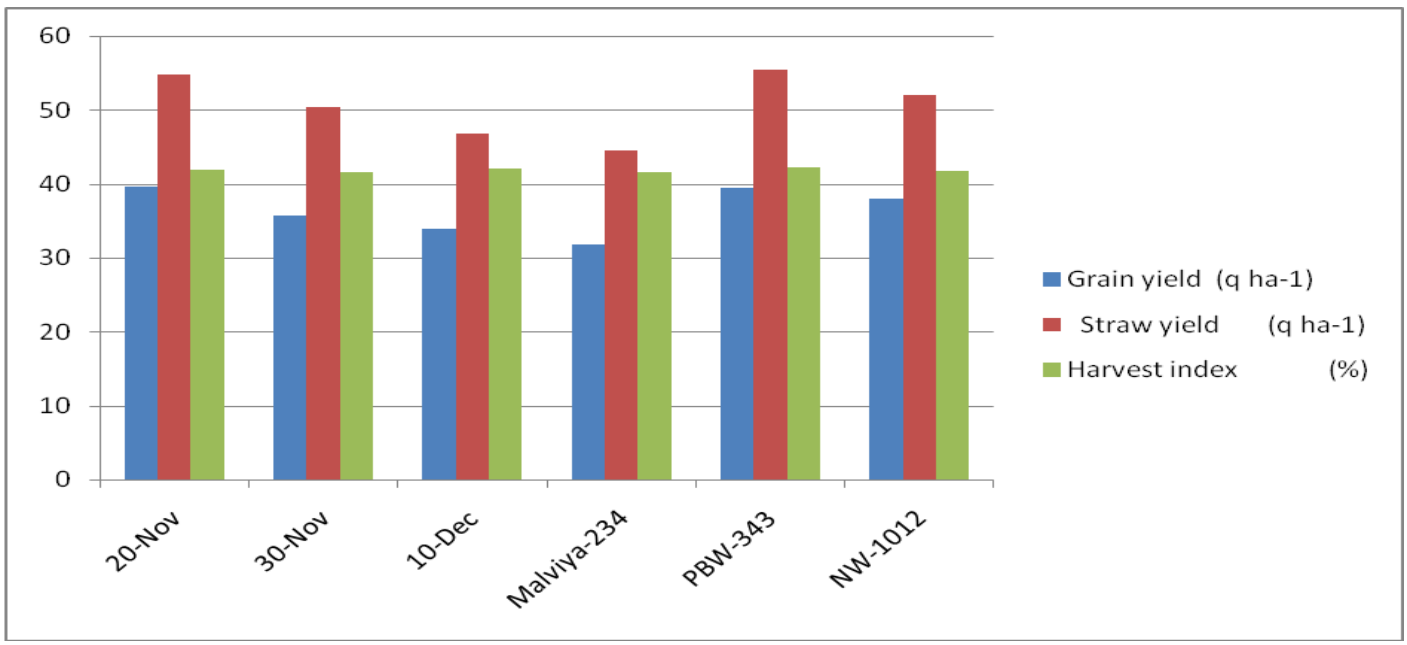


Fig.8 Economics of various treatment combinations

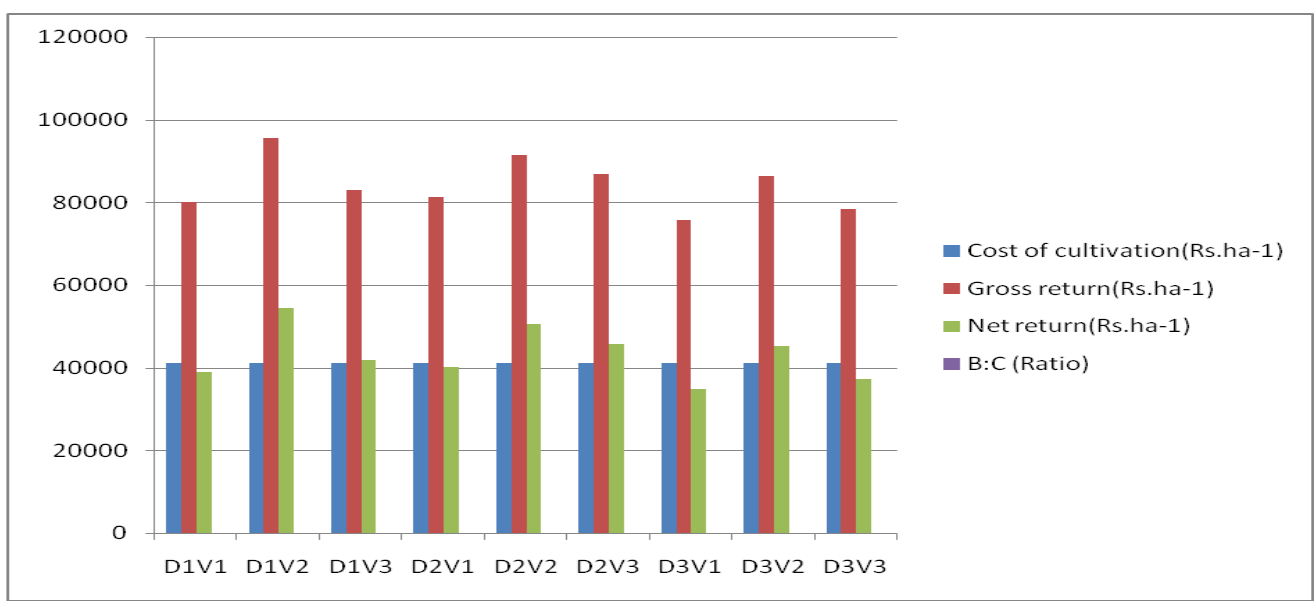

The highest days (94.00) and (92.33) were taken to $50 \%$ ear emergence with 20 November date of sowing along cultivar PBW-343. The highest days (127.00) and (125.33) were taken to maturity with 20 November date of sowing along cultivar PBW-343. The maximum grain yield $39.45 \mathrm{q}$ $\mathrm{ha}^{-1}$ was recorded with cultivar PBW-343 which was significantly higher over rest of the cultivars. The maximum cost of cultivation (Rs.41033 ha $\mathrm{ha}^{-1}$ ) was computed at cultivar PBW-343 ha ${ }^{-1}$ with both level of date of sowing. The maximum gross return (Rs. $95580 \mathrm{ha}^{-1}$ ) was recorded under the treatment combination of 20 November date of sowing with cultivar PBW-343. The minimum gross return (Rs.75837 ha ${ }^{-1}$ ) was found with 10 December of sowing with cultivar Malviya234. Highest net return (Rs. $54547 \mathrm{ha}^{-1}$ ) was found under the treatment combination of 20 November date of sowing with cultivar PBW343. The lowest net return (Rs. $34804 \mathrm{ha}^{-1}$ ) was recorded under 10 December date of sowing with cultivar Malviya-234. As regards benefit cost ratio, the maximum benefit cost ratio (1.33) was obtained from treatment combination of 20 November date of sowing with cultivar PBW-343 followed by 1.23and 1.11 obtained from treatment combination of 30 November date of sowing with cultivar PBW-343 and 30 November date of sowing with cultivar NW-1012. The lowest benefit cost ratio (0.85) was obtained with 10 December date of sowing cultivar Malviya234.

Sowing dates significantly influenced the growth characters of wheat crop. The crop sown on 20 November recorded highest initial plant population $\left(\mathrm{m}^{-2}\right)$, plant height $(\mathrm{cm})$, number of tillers $\mathrm{m}^{-2}$, drymatter accumulation $\left(\mathrm{g} \mathrm{m}^{-2}\right)$, leaf area index, days taken to $50 \%$ ear emergence and days taken to maturity followed by 30 November and 10 December sown crops, respectively. Among the cultivars PBW-343 was found superior in all growth characters than other varieties. PBW-343 also recorded highest initial plant population $\left(\mathrm{m}^{-2}\right)$, plant height $(\mathrm{cm})$, number of tillers $\mathrm{m}^{-2}$, drymatter accumulation $\left(\mathrm{g} \mathrm{m}^{-2}\right)$, leaf area index, days taken to $50 \%$ ear emergence and days taken to maturity. Maximum benefit cost ratio (1.33) was obtained from treatment combination of 20 November date of sowing with cultivar PBW-343.

In conclusion on the basis of foregoing discussion and the results of investigation, it can be concluded that sowing of wheat crop on $20^{\text {th }}$ November was most suitable for higher productivity and return of wheat, among the cultivars, PBW-343 found suitable 
cultivar of wheat to achieve higher growth, productivity and economics.

\section{References}

Alexander, B, Hayman, P, Mc, Donald, G, Talukder, H, A.S.M.Gill, G(2010), Characterizing the risk of heat stress on wheat in South Australia: Meteorology, climatology and the design of a field heating chamber. In: Dove, H. (Ed.), Food Security from Sustainable Agriculture: Proceedings of 15th Agronomy Conference 2010. Lincoln, New Zeeland.

Bhardwaj, V, Yadav, V and Chauhai, BS(2010). Effect of nitrogen application timings and varieties on growth and yield of wheat grown on raised beds, Archives of Agronomy and Soil Science, 56(2), 211-222.

DAC, 2014-2015. Department of Agriculture and Cooperation, GOI. Agricultural Statistics at a Glance-2014-2015. Available at: http://eands.dacnet.nic.in/At_A_Glanc e_2015/4.7(a).xls

DEFRA, 2005. India-UK collaboration on impacts of climate change in India. http: //www. defra. ov.uk/envirnviro $\mathrm{nm} \quad \mathrm{e}$ nt/cli mate change/intemat/devcountry/india2.htm (accessed 18 April 2006).

Deshmukh, KM, Nayak, SK, Damdar, Rupali and Wanjiri, SS(2015), Response of different wheat genotypes to different sowing time in relation to GDD accumulation, Advance research journal of crop Improvement, 6 (2), 66-72.

Dhaka, AK, Bangarwa, AS, Pannu, RK, Malik, RK and Garg, R(2006), Phenological development, yield and yield attributes of different wheat genotypes as influenced by sowing time and irrigation levels, Agricultural
Science Digest 26(3), 174-177.

Jat, Kumar, Lokesh, Singh SK, Latare, AM, Singh, RS and Patel, CB(2013), Effect of dates of sowing and fertilizer on growth and yield of wheat (Triticum aestivum) in an Inceptisol of Varanasi, Indian Journal of Agronomy, 58(4), 611-614.

Keeling, PL, Banisadr, R, Barone, L, Wasserman, BP and Singletary, GW(1994), Effect of temperature on enzymes in the pathway of starch biosynthesis in developing wheat andmaize grain, Australian Journal of Plant Physiology 21,807-827.

Kumar, D, Singh, RA and Singh, Y(2016), Influence of sowing dates and nitrogen scheduling on growth behaviour and productivity of late sown wheat (Triticum aestivum L.) in north Indian plains, Annals of Agriculture Research New Kumar, S, Alam, P and Ali, N(2013), Response of wheat varieties to sowing dates, Journal of Research (BAU), 25(1), 56-59.

Marasini, D, Marahatta, S, Dhungana, SM and Acharya, R(2016), Effect of date of sowing on yield and yield attributes of different wheat varieties under conventional tillage in sub humid condition of Chitwan district of Nepal, International Journal of Applied Science Biotechnology, 4(1), 27-31.

Mattas, KK, Uppal, RS and Singh, RP(2011),Effect ofvarieties and nitrogen management on the growth, yield and nitrogen uptake of durum wheat, Research Journal of Agricultural Sciences 2(2), 376-380.

Mumtaz, MA, Aslam, M, Nasrullah, HM, Akhtar, M and Ali, B(2015), Effect of Various Sowing Dates on Growth, Yield and Yield Components of Different Wheat Genotypes, American-Eurasian Journal of Agriculture \& Environment Science, 
15 (11),2230-2234.

Musaddique, M, Hussain, A, Wajid, SA and Ahmad, A(2000), Growth, yield and components of yield of different genotypes of wheat, International Journal of Agriculture \& Biology, 2(3), 242-244.

Shahzad, MA, Wasi-ud-Din, Sahi, Khan, ST, Ehsanullah, MM and Ahmad, M(2007), Effect of sowing dates and seed treatment on grain yield and quality of wheat, Pakistan Journal of Agricultural Science, 44(4), 581-583.

Sharma, SN, Wheat in: Rathore, P.S. (Ed.)(2000), Techniques and Management of Field Crop Production. Agrobios, India.
Singh, B(2005), To assess the performance of new wheat varieties under late sown conditions with different nitrogen levels, MSc. (Ag.) Thesis, N.D.U.A.\&T., Kumarganj, Faizabad.

Spiertz, JHL, Hamer, RJ, Xu, H, PrimoMartin, C, Don, $\mathrm{C}$ and van der Putten, PEL(2006), Heat stress in wheat (Triticum aestivum L.): effect on grain growth and quality traits, Europian Journal of Agronomy, 23, 89-95.

Tubiello, FN, Rosenzweig, C, Goldberg, RA, Jagtap, S and Jones, JW(2000), U.S. National Assessment Technical Report Effects of Climate Change on U.S. Crop Production Part I: Wheat, Potato, Corn, and Citrus.

\section{How to cite this article:}

Sanjay Singh Chauhan, Anil Kumar Singh, Shipra Yadav, Sandeep Kumar Verma and Rahul Kumar. 2020. Effect of Different Varieties and Sowing Dates on Growth, Productivity and Economics of Wheat (Triticum aestivum L.). Int.J.Curr.Microbiol.App.Sci. 9(02): 2630-2639. doi: https://doi.org/10.20546/ijcmas.2020.902.300 